\title{
ON THE SOLUTION OF CONFORMABLE FRACTIONAL HEAT CONDUCTION EQUATION
}

\author{
Bilender Pasaoglu${ }^{1}$, Hüseyin TUNA ${ }^{2}$, and YÜKSEL YALÇINKAYA ${ }^{3}$ \\ ${ }^{1}$ Suleyman Demirel Universitesi \\ ${ }^{2}$ Mehmet Akif Ersoy University \\ ${ }^{3}$ SULEYMEN DEMIREL UNIVERSITY
}

May 5, 2020

\begin{abstract}
In this article, we sudy conformable fractional heat conduction equation. Applying the method of seperation variables to this problem, we get a conformable Sturm-Liouville eigenvalue problem. Later, we prove the existence of a countably infinite set of eigenvalues and eigenfunctions. Finally, we establish uniformly convergent expansions in the eigenfunctions.
\end{abstract}

\section{Hosted file}

Eigenfunction Expansions for a Sturm--Liouville-swp.pdf available at https://authorea.com/ users/301067/articles/430844-on-the-solution-of-conformable-fractional-heat-conductionequation 